\title{
NOC/oFQ and NMDA Contribute to Piglet Hypoxic Ischemic Hypotensive Cerebrovasodilation Impairment
}

\author{
WILLIAM M. ARMSTEAD \\ Departments of Anesthesia and Pharmacology, University of Pennsylvania, Philadelphia, Pennsylvania \\ 19104, U.S.A.
} \begin{abstract}
ABST
Previous studies have observed that hypotensive pial artery
dilation was blunted after hypoxia-ischemia. In unrelated studies, the opioid nociceptin/orphanin FQ (NOC/oFQ) was observed to contribute to hypoxic ischemic impairment of $N$-methyl-Daspartate (NMDA)-induced pial dilation. This study determined the contribution of NOC/oFQ and NMDA to hypoxic ischemic hypotensive cerebrovasodilation impairment in newborn pigs equipped with a closed cranial window. Global cerebral ischemia was produced via elevated intracranial pressure. Hypoxia decreased $\mathrm{Po}_{2}$ to $33 \pm 3 \mathrm{~mm} \mathrm{Hg}$. Topical NOC/oFQ $\left(10^{-10} \mathrm{M}\right)$, the cerebrospinal fluid concentration after hypoxia-ischemia, had no effect on pial artery diameter by itself but attenuated hypotension (mean arterial blood pressure decrease of $44 \pm 2 \%$ ) -induced pial artery dilation $(35 \pm 2 \%$ versus $22 \pm 3 \%$ ). Hypotensive pial artery dilation was blunted by hypoxia-ischemia, but such dilation was partially protected by pretreatment with the putative NOC/oFQ receptor antagonist, [F/G] NOC/oFQ (1-13) $\mathrm{NH}_{2}$ $\left(10^{-6} \mathrm{M} ; 29 \pm 2 \%\right.$, sham control; $7 \pm 2 \%$, hypoxia-ischemia; and $13 \pm 2 \%$, hypoxia-ischemia and $[\mathrm{F} / \mathrm{G}]$ NOC/oFQ (1-13)
\end{abstract}

$\left.\mathrm{NH}_{2}\right)$. Coadministration of the NMDA antagonist MK801 $\left(10^{-5}\right.$ $\mathrm{M})$ with $\mathrm{NOC} / \mathrm{oFQ}\left(10^{-10} \mathrm{M}\right)$ partially prevented hypotensive pial dilation impairment. Similarly, pretreatment with MK801 partially protected hypoxic ischemia impairment of hypotensive pial dilation $(35 \pm 2 \%$, sham control; $7 \pm 1 \%$, hypoxiaischemia; $22 \pm 2 \%$, hypoxia-ischemia + MK801). These data show that NOC/oFQ and NMDA contribute to hypoxic ischemic hypotensive cerebrovasodilation impairment. These data suggest that NOC/oFQ modulation of NMDA vascular activity also contributes to such hypotensive impairment. (Pediatr Res 51: 586-591, 2002)
H/I, hypoxia-ischemia

\section{Abbreviations}
CSF, cerebrospinal fluid
$\mathbf{H} / \mathbf{I} / \mathbf{R}$, hypoxia-ischemia-reperfusion
NOC/oFQ, nociceptin/orphanin FQ
NMDA, $N$-methyl-D-aspartate

Episodes of inadequate oxygen supply to the brain can result in significant neurologic sequelae. Babies are frequently exposed to either combined or sequential hypoxia and ischemia insults during the perinatal period because of problems with delivery or respiratory management after delivery (1). One contributor to neurologic damage is thought to be cerebrovascular dysfunction. For example, the major neurologic manifestations of brain injury in the premature infant are spastic motor deficits (1). The major neuropathologic outcomes for the latter are periventricular leukomalacia and periventricular hemorrhagic infarction (1). One contributor to periventricular leukomalacia is the pressure-passive cerebral circulation, which, in turn, can result from systemic hypotension (1). One potential

Received June 29, 2001; accepted December 13, 2001.

Correspondence and reprint requests: William M. Armstead, Ph.D., Department of Anesthesia, University of Pennsylvania,3400 Spruce Street, Philadelphia, PA 19104, U.S.A.; e-mail: armsteaw@mail.med.upenn.edu

Supported by grants from the National Institutes of Health and the University of Pennsylvania Research Foundation. pathogenic factor in such white matter injury is excess extracellular glutamate, an excitatory amino acid (1). However, little attention has been paid to the functional implications of vascular abnormalities to glutamate after an H/I insult.

During the last $5 \mathrm{y}$, several groups have isolated and cloned a new $G$ protein-coupled receptor that showed high homology with opioid receptors (2). The peptide ligand for this receptor does not bind to classic opioid receptors $(\mu, \delta, \kappa)$ and was named orphanin FQ by Reinscheid et al. (3) because its sequence begins with phenylalanine (F) and ends with glutamine (Q). The same peptide was called nociceptin by Meunier et al. (4) because it increased the reactivity to pain in animals in contrast with the analgesic effects of opioid drugs. However, little is known about the role of NOC/oFQ in the physiologic or pathophysiologic control of cerebral hemodynamics. Recent studies have shown that the CSF concentration of NOC/oFQ is elevated to approximately $10^{-10} \mathrm{M}$ after $\mathrm{H} / \mathrm{I}$ in the piglet $(5,6)$. Interestingly, it has also been observed to contribute to the reduction in cerebral blood flow that occurs 
after $\mathrm{H} / \mathrm{I}(5)$, as well to impaired glutamate- and NMDA-, a subtype of glutamate receptor, induced pial artery dilation after this insult (6). Finally, NOC/oFQ has been observed to exacerbate excitotoxic white matter lesions in a murine neonatal brain injury model (7).

Previous studies using a piglet model of global cerebral ischemia have observed that the ability of pial arteries to dilate during hypotension was impaired (8). However, the mechanism for such impairment is uncertain. This study, therefore, was designed to determine the contribution of NOC/oFQ and NMDA to $\mathrm{H} / \mathrm{I}$ hypotensive cerebrovasodilation impairment in the newborn pig. In particular, this study determined l) the ability of $\mathrm{NOC} / \mathrm{oFQ}$, in concentrations present in CSF after $\mathrm{H} / \mathrm{I}$, to modulate hypotensive pial artery dilation, 2) the contribution of NOC/oFQ to impaired hypotensive pial dilation after $\mathrm{H} / \mathrm{I}, 3)$ the role of NMDA in NOC/oFQ modulation of hypotensive pial dilation, and 4) the contribution of NMDA to hypotensive dilation impairment after H/I.

\section{METHODS}

Newborn (1-5 d old, 1.3-2.1 kg) pigs of either sex were used in these experiments. All protocols were approved by the Institutional Animal Care and Use Committee. Piglets were initially anesthetized with isoflurane (1-2 minimum alveolar concentration). Anesthesia was maintained with $\alpha$-chloralose $\left(30-50 \mathrm{mg} / \mathrm{kg}\right.$, supplemented with $5 \mathrm{mg} \cdot \mathrm{kg}^{-1} \cdot \mathrm{h}^{-1}$ iv). A catheter was inserted into a femoral artery to monitor blood pressure and to sample for blood gas tensions and $\mathrm{pH}$. Drugs to maintain anesthesia were administered through a second catheter placed in a femoral vein. The trachea was cannulated, and the animals were mechanically ventilated with room air. A heating pad was used to maintain the animals at $37-39^{\circ} \mathrm{C}$.

A cranial window was placed in the parietal skull of these anesthetized animals. This window consisted of three parts: a stainless-steel ring, a circular glass coverslip, and three ports consisting of 17-gauge hypodermic needles attached to three precut holes in the stainless-steel ring. For placement, the dura was cut and retracted over the cut bone edge. The cranial window was placed in the opening and cemented in place with dental acrylic. The volume under the window was filled with a solution, similar to CSF, of the following composition (in $\mathrm{mM}): 3.0 \mathrm{KCl}, 1.5 \mathrm{MgCl}_{2}, 1.5 \mathrm{CaCl}_{2}, 132 \mathrm{NaCl}, 6.6$ urea, 3.7 dextrose, and $24.6 \mathrm{NaHCO}_{3}$. This artificial CSF was warmed to $37^{\circ} \mathrm{C}$ and had the following chemistry: $\mathrm{pH} 7.33, \mathrm{PCO}_{2} 46 \mathrm{~mm}$ $\mathrm{Hg}$, and $\mathrm{Po}_{2} 43 \mathrm{~mm} \mathrm{Hg}$, which was similar to that of endogenous CSF. Pial arterial vessels were observed with a dissecting microscope, a television camera mounted on the microscope, and a video output screen. Vascular diameter was measured with a video microscaler. For production of cerebral ischemia, a hollow stainless-steel bolt was implanted in a small $(2 \mathrm{~mm})$ hole in the skull.

Protocol. Two types of pial arterial vessels, small arteries (resting diameter, 120-160 $\mu \mathrm{m}$ ) and arterioles (resting diameter, 50-70 $\mu \mathrm{m}$ ), were examined to determine whether segmental differences in the effects of $\mathrm{H} / \mathrm{I}$ could be identified. Pial arterial vessel diameter was determined every minute for a 10-min exposure period after infusion onto the exposed parietal cortex of artificial CSF before drug application and after infusion of artifical CSF containing a drug. Typically, 2-3 mL of CSF was flushed through the window for a 30 -s period, and excess CSF was allowed to run off through one of the needle ports.

Techniques for induction of total cerebral ischemia in the piglet have been well documented $(8,9)$. Briefly, total cerebral ischemia was accomplished by infusing artificial CSF into a hollow bolt in the cranium to maintain an intracranial pressure $15 \mathrm{~mm} \mathrm{Hg}$ greater than the numeric mean of systolic and diastolic arterial blood (9). Intracranial pressure was monitored via a sidearm of the cranial window. Blood flow in pial arterioles, viewed with a microscope and video monitor, stopped completely on elevation of intracranial pressure and did not resume until the pressure was lowered (9). To prevent the arterial pressure from rising inordinately (Cushing response), venous blood was withdrawn as necessary to maintain mean arterial pressure no greater than $100 \mathrm{~mm} \mathrm{Hg}$. As the cerebral ischemic response subsided, the shed blood was returned to the animal. Cerebral ischemia was maintained for 20 min. In combined $H / I / R$ animals, in which $R$ is reperfusion, hypoxia $\left(\mathrm{Po}_{2}, 33 \pm 3 \mathrm{~mm} \mathrm{Hg}\right)$ was produced for $10 \mathrm{~min}$ before ischemia by decreasing the inspired $\mathrm{O}_{2}$ via inhalation of $\mathrm{N}_{2}$, which was immediately followed by the total ischemia protocol as described above after concomitantly restoring ventilation to room air.

Six major types of experiments were performed (all $n=7$ ): 1) vascular responses to hypotension in the absence of $\mathrm{H} / \mathrm{I} / \mathrm{R}$ (sham control), 2) vascular responses to hypotension in the absence and presence of coadministered NOC/oFQ, 3) vascular responses to hypotension before and after $\mathrm{H} / \mathrm{I} / \mathrm{R}, 4$ ) vascular responses to hypotension after $\mathrm{H} / \mathrm{I} / \mathrm{R}$ in $[\mathrm{F} / \mathrm{G}] \mathrm{NOC} / \mathrm{oFQ}(1-$ 13) $\mathrm{NH}_{2}$-pretreated animals, 5) vascular responses to hypotension in the absence and presence of coadministered NOC/oFQ and MK801, and 6) vascular responses to hypotension after H/I/R in MK801-pretreated animals. Two levels of hypotension (moderate and severe) designed to lower mean arterial blood pressure by approximately 25 and $45 \%$ were investigated. Hypotension was induced by rapidly withdrawing either $5-8$ or $10-15 \mathrm{~mL}$ blood $/ \mathrm{kg}$. Such a drop in mean blood pressure was maintained constant for $10 \mathrm{~min}$ by titration of additional blood withdrawal $(1-5 \mathrm{~mL})$ to keep arterial blood pressure from rising and by blood reinfusion $(1-5 \mathrm{~mL})$ to keep pressure from falling. The percent changes in artery diameter values were calculated on the basis of the diameter measured in the control period before hypotension.

Responses to hypotension were obtained before and after 60 min of reperfusion in $\mathrm{H} / \mathrm{I}$ animals in the absence and presence of either the NOC/oFQ receptor antagonist, $[\mathrm{F} / \mathrm{G}] \mathrm{NOC} / \mathrm{oFQ}$ (1-13) $\mathrm{NH}_{2}\left(10^{-6} \mathrm{M}\right)$ or the NMDA antagonist, MK801 $\left(10^{-5}\right.$ M). In antagonist-pretreated animals, the respective agents were administered $30 \mathrm{~min}$ before H/I. Confirmation of adequate receptor blockade was determined by comparing responses to either NOC/oFQ $\left(10^{-8}, 10^{-6} \mathrm{M}\right)$ before and after [F/G] NOC/oFQ (1-13) $\mathrm{NH}_{2}$ or NMDA before and after MK801.

Statistical analysis. Pial artery diameter and systemic arterial pressure were analyzed for repeated measures. If the $F$ 
value was significant, the data were then analyzed by Fisher's protected least significant difference. An $\alpha$ level of $p<0.05$ was considered significant in all statistical tests. Values are presented as mean \pm SEM of absolute values or as percentages of change from control values.

\section{RESULTS}

Interaction of NOC/oFQ with hypotension-induced pial artery dilation. Two levels of hypotension (moderate and severe) elicited reproducible graded pial small artery (120-160 $\mu \mathrm{m})$ and arteriole $(50-70 \mu \mathrm{m})$ dilation in sham control animals. Moderate hypotension decreased mean arterial blood pressure by $24 \pm 1 \%$ whereas severe did so by $44 \pm 2 \%$. Pretreatment with NOC/oFQ $\left(10^{-10} \mathrm{M}\right)$, the concentration observed in $\mathrm{CSF}$ after $\mathrm{H} / \mathrm{I}$, diminished pial dilation to both levels of hypotension (Fig. 1). NOC/oFQ $\left(10^{-10} \mathrm{M}\right)$ had no effect on pial artery diameter by itself $(140 \pm 6$ versus $142 \pm$ $6 \mu \mathrm{m}, n=7)$. On a percentage basis, NOC/oFQ impaired hypotensive pial small artery and arteriole dilation by $45 \pm 7 \%$ and $42 \pm 6 \%$ during the moderate hypotension and by $37 \pm$ $6 \%$ and $39 \pm 5 \%$ during severe hypotension.

Role of NOC/oFQ in impaired hypotension-induced pial artery dilation after $\mathrm{H} / \mathrm{I}$. Pial small artery and arteriole dilation in response to both levels of hypotension was blunted within $1 \mathrm{~h}$ after H/I (Fig. 2). On a percentage basis, H/I/R decreased pial small artery dilation during moderate hypotension by $77 \pm$ $6 \%$ and by $78 \pm 7 \%$ during severe hypotension. Similar inhibition was observed in pial arterioles. Pretreatment with [F/G] NOC/oFQ (1-13) $\mathrm{NH}_{2}\left(10^{-6} \mathrm{M}\right)$, an NOC/oFQ receptor antagonist, $30 \mathrm{~min}$ before insult partially protected reduced

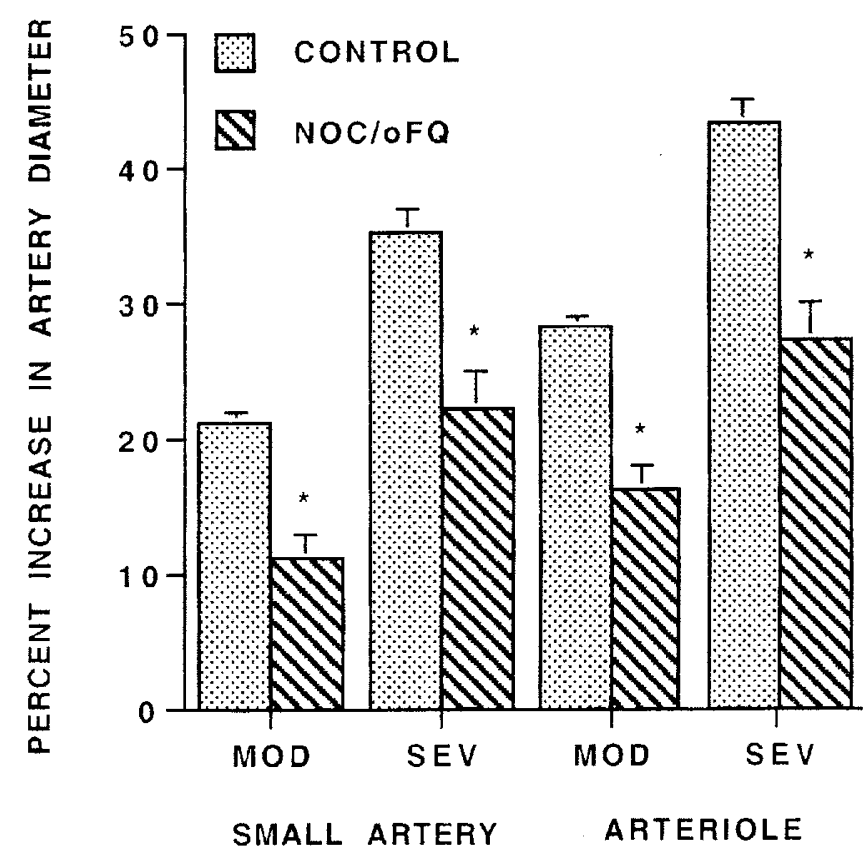

\section{HYPOTENSION}

Figure 1. Influence of moderate (mod) and severe (sev) hypotension on pial small artery and arteriole diameter in the absence (control) and presence of NOC/oFQ $\left(10^{-10} \mathrm{M} ; n=7\right.$ each). ${ }^{*} p<0.05$ compared with control. hypotensive pial dilation at $1 \mathrm{~h}$ of reperfusion (Fig. 2). This NOC/oFQ receptor antagonist had no effect on pial diameter by itself (138 \pm 5 versus $139 \pm 6 \mu \mathrm{m}, n=7)$. On a percentage basis, H/I/R decreased pial small artery dilation in such pretreated animals by $36 \pm 9 \%$ during moderate and by $34 \pm 8 \%$ during severe hypotension. Similar inhibition was observed in pial arterioles. Administration of [F/G] NOC/oFQ (1-13) $\mathrm{NH}_{2}$ blocked vascular responses to NOC/oFQ $\left(10^{-8}, 10^{-6} \mathrm{M}\right)$ to an equal extent before and after $\mathrm{H} / \mathrm{I}$.

Role of NMDA in NOC/oFQ-associated impairment of hypotensive pial artery dilation in sham and $\mathrm{H} / \mathrm{I}$ animals. Coadministration of the NMDA antagonist MK801 $\left(10^{-5} \mathrm{M}\right)$ with NOC/oFQ $\left(10^{-10} \mathrm{M}\right)$ partially protected reduced hypotensive pial artery dilation compared with the response observed with NOC/oFQ alone in sham control animals (Fig. 3). On a percentage basis, NOC/oFQ impaired pial small artery dilation during moderate hypotension by $22 \pm 3 \%$ in such pretreated animals. Similarly, MK801 pretreatment $30 \mathrm{~min}$ before $\mathrm{H} / \mathrm{I}$ partially protected reduced hypotensive pial dilation at $1 \mathrm{~h}$ of reperfusion (Fig. 4). On a percentage basis, H/I/R impaired pial artery dilation by $21 \pm 5 \%$ during moderate hypotension in MK801-pretreated animals. Such protection by MK801 was significantly greater than that observed with $[\mathrm{F} / \mathrm{G}]$ NOC/oFQ (1-13) $\mathrm{NH}_{2}$ described above. Similar protection was observed in pial arterioles. NMDA-induced pial artery dilation was blocked by MK801 $\left(10^{-5} \mathrm{M} ; 16 \pm 1 \%\right.$ and $25 \pm$ $1 \%$ versus $1 \pm 1 \%$ and $2 \pm 1 \%$ for NMDA $10^{-8}, 10^{-6} \mathrm{M}$, before and after MK801, respectively). Similar inhibition of

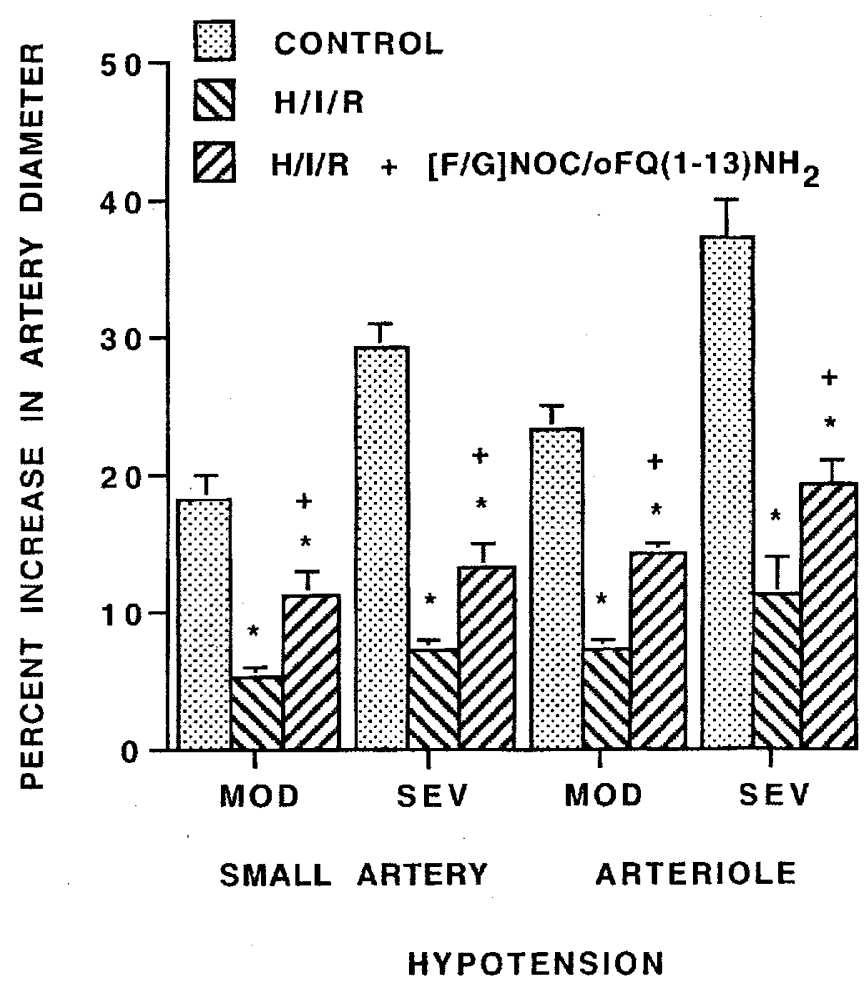

Figure 2. Influence of moderate (mod) and severe (sev) hypotension on pial small artery and arteriole diameter before (control), after $\mathrm{H} / \mathrm{I} / \mathrm{R}$, and after $\mathrm{H} / \mathrm{I} / \mathrm{R}$ in $[\mathrm{F} / \mathrm{G}] \mathrm{NOC} / \mathrm{oFQ}(1-13) \mathrm{NH}_{2}\left(10^{-6} \mathrm{M}\right)$-pretreated animals $\left(n=7\right.$ each). ${ }^{*} p$ $<0.05$ compared with control; $+p<0.05$ compared with $\mathrm{H} / \mathrm{I} / \mathrm{R}$ nonpretreated value. 


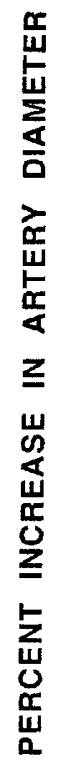

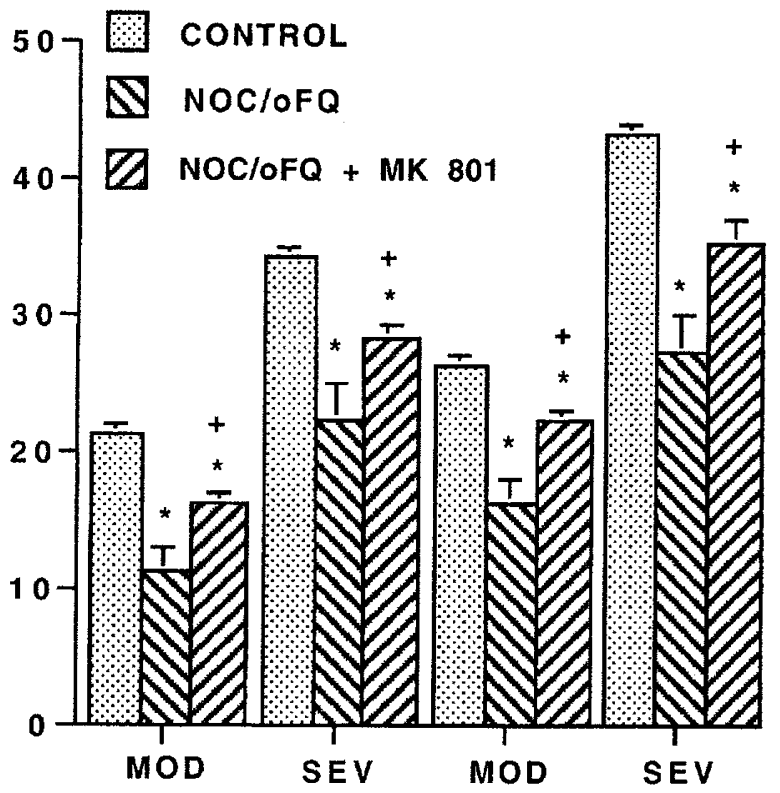

SMALL ARTERY ARTERIOLE

\section{HYPOTENSION}

Figure 3. Influence of moderate (mod) and severe (sev) hypotension on pial artery small artery and arteriole diameter in the absence (control), presence of NOC/oFQ $\left(10^{-10} \mathrm{M}\right)$, and presence of coadministered NOC/oFQ and MK801 $\left(10^{-5} \mathrm{M} ; n=7\right.$ each). ${ }^{*} p<0.05$ compared with control; $+p<0.05$ compared with absence of MK801.

NMDA vascular activity by MK801 was observed after H/I. A summary of the interaction between NOC/oFQ and in impaired hypotensive pial artery dilation is shown in Table 1.

Blood chemistry. Blood chemistry and mean arterial blood pressure values were obtained at the beginning and end of all experiments as well as during hypoxia. Hypoxia decreased $\mathrm{Po}_{2}$ to $33 \pm 3 \mathrm{~mm} \mathrm{Hg}$, whereas the $\mathrm{pH}, \mathrm{PCO}_{2}$, and mean arterial blood pressure values were unchanged. Values for $\mathrm{pH}, \mathrm{PCO}_{2}$, $\mathrm{P}_{2}$, and mean arterial blood pressure were $7.45 \pm 0.02,34 \pm$ $4 \mathrm{~mm} \mathrm{Hg}, 91 \pm 6 \mathrm{~mm} \mathrm{Hg}$, and $68 \pm 6 \mathrm{~mm} \mathrm{Hg}$, respectively, at the start of experiments versus $7.44 \pm 0.02,35 \pm 6 \mathrm{~mm} \mathrm{Hg}$, $94 \pm 7 \mathrm{~mm} \mathrm{Hg}$, and $69 \pm 7 \mathrm{~mm} \mathrm{Hg}$, respectively, at the end of experiments. There were no group differences in either blood pressure or blood chemistry values.

\section{DISCUSSION}

Results of the present study show that coadministration of $\mathrm{NOC} / \mathrm{oFQ}$, in a concentration observed in cortical periarachnoid CSF after $\mathrm{H} / \mathrm{I}\left(10^{-10} \mathrm{M}\right)(5,6)$, with hypotension attenuated pial artery vasodilation in response to this stimulus. Because this concentration of NOC/oFQ had no effect on pial artery diameter by itself, diminished hypotensive dilation did not result from physiologic antagonism. Although the precise concentration at the receptor level is uncertain, these data suggest that such concentrations of NOC/oFQ observed after $\mathrm{H} / \mathrm{I}$ could have physiologic significance. Because dilation of both pial small artery and arteriole during hypotension was impaired equally, these data suggest that there are minimal

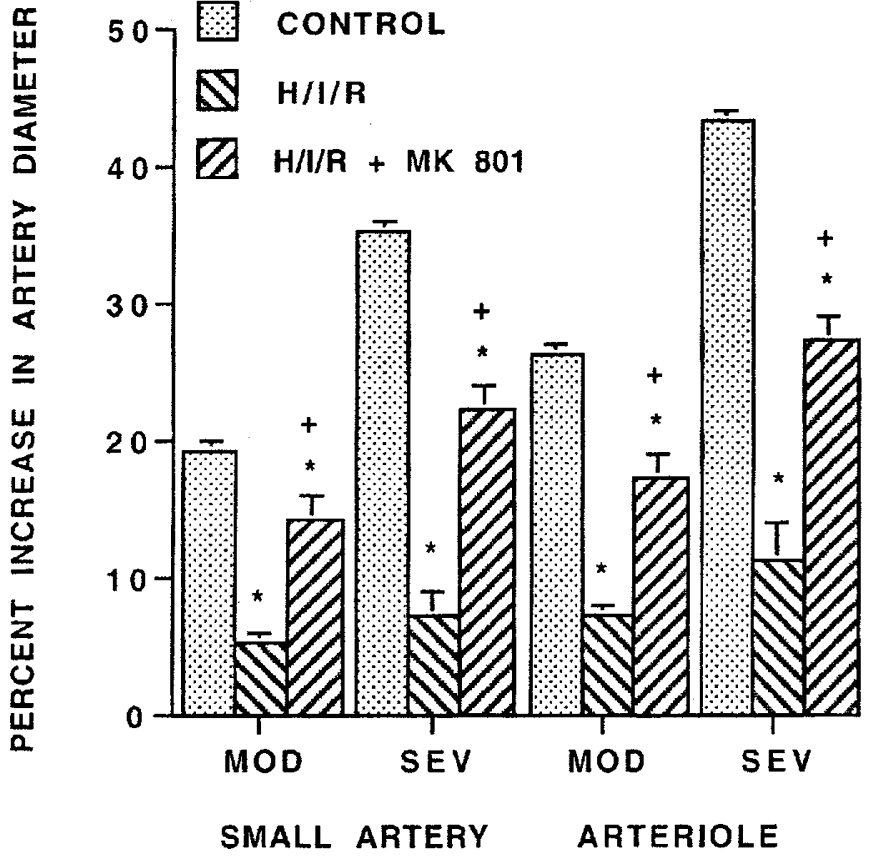

\section{HYPOTENSION}

Figure 4. Influence of moderate (mod) and severe (sev) hypotension on pial small artery and arteriole diameter before (control), after $\mathrm{H} / \mathrm{I} / \mathrm{R}$, and after $\mathrm{H} / \mathrm{I} / \mathrm{R}$ in MK801 $\left(10^{-5} \mathrm{M}\right)$-pretreated animals $\left(n=7\right.$ each). ${ }^{*} p<0.05$ compared with control; $+p<0.05$ compared with $\mathrm{H} / \mathrm{I} / \mathrm{R}$ nonpretreated value.

Table 1. Summary of relationships between $N O C / O F Q, N M D A$, and hypotensive pial artery dilation in sham and H/I animals

\begin{tabular}{|c|c|c|}
\hline & \multicolumn{2}{|c|}{ Hypotensive pial artery dilation } \\
\hline & Sham & $\mathrm{H} / \mathrm{I}$ \\
\hline NOC/oFQ & impairs & impairs \\
\hline NMDA & $\begin{array}{l}\text { NOC/oFQ contributes } \\
\text { to impairment }\end{array}$ & $\begin{array}{l}\text { impairs; NOC/oFQ contributes } \\
\text { to impairment }\end{array}$ \\
\hline
\end{tabular}

regional vascular differences in the inhibitory action of NOC/ oFQ. Similarly, because both levels of hypotension-induced pial dilation were equivalently inhibited, these data indicate that such inhibition is independent of stimulus potency.

A second series of experiments was designed to determine the functional significance of the above interaction between NOC/oFQ and hypotensive pial dilation. Results of these studies show that $\mathrm{H} / \mathrm{I}$ blunted hypotensive pial artery dilation at $1 \mathrm{~h}$ of reperfusion, similar to those previously published for cerebral ischemia without prior hypoxia (8). However, new data from this study show that the NOC/oFQ receptor antagonist $[\mathrm{F} / \mathrm{G}] \mathrm{NOC} / \mathrm{oFQ}(1-13) \mathrm{NH}_{2}$ partially prevented such diminished hypotensive pial dilation after $\mathrm{H} / \mathrm{I}$. These data suggest the involvement of NOC/oFQ release after $\mathrm{H} / \mathrm{I}$ in altered hypotensive dilation after this insult. Similar to results obtained with NOC/oFQ coadministered during hypotension in sham control animals, [F/G] NOC/oFQ (1-13) $\mathrm{NH}_{2}$ elicited partial prevention of $\mathrm{H} / \mathrm{I}$ impairment of hypotensive dilation to a roughly equal extent in both pial small arteries and arterioles during both levels of the hypotensive stimulus. Therefore, minimal regional vascular differences were observed, and such 
impairment was again independent of stimulus potency. Although somewhat controversial as a selective NOC/oFQ receptor antagonist $(10,11),[\mathrm{F} / \mathrm{G}] \mathrm{NOC} / \mathrm{oFQ}(1-13) \mathrm{NH}_{2}$ has been observed to block NOC/oFQ $\left(10^{-8}, 10^{-6} \mathrm{M}\right)$-induced pial artery dilation but to have no effect on the vascular response to the endogenous opioids methionine enkephalin, leucine enkephalin, dynorphin, and $\beta$ endorphin or the synthetic opioids [D Ala ${ }^{2}, \mathrm{~N}-\mathrm{Me}-\mathrm{Phe}^{4}, \mathrm{Gly}^{5}$-Ol]-Enkephalin (DAMGO), [D-Pen $\left.{ }^{2,5}\right]$ Enkephalin (DPDPE), deltorphin, and U50,488H, $\mu, \delta_{1}, \delta_{2}$, and $\kappa$ opioid selective agonists (12). These data indicate that $[\mathrm{F} / \mathrm{G}]$ NOC/oFQ (1-13) $\mathrm{NH}_{2}$ is a selective NOC/oFQ receptor antagonist in the piglet cerebral circulation.

Additional experiments were designed to characterize the role of NMDA receptor activation in NOC/oFQ-associated impairment of hypotensive pial artery dilation in sham control and H/I animals. Results of these studies show that the NMDA receptor antagonist MK801 partially protected reduced hypotensive pial artery dilation both when coadministered with NOC/oFQ $\left(10^{-10} \mathrm{M}\right)$ in sham control animals and after H/I. These results suggest that NMDA receptor activation contributes to NOC/oFQ-induced impairment of hypotensive pial dilation in sham control and $\mathrm{H} / \mathrm{I}$ animals. Although uncertainty exists as to the mechanism that might link NOC/oFQ to NMDA receptor activation in effecting hypotensive pial dilation impairment, one possibility could relate to the previously observed ability of NOC/oFQ to contribute to the reversal of NMDA from a vasodilator to a vasoconstrictor via superoxide generation after $\mathrm{H} / \mathrm{I}(6,13)$. In that case, NOC/oFQ-induced impairment of NMDA dilation might physiologically antagonize pial artery dilation during hypotension. However, as MK801 afforded greater protection of hypotensive dilation after $\mathrm{H} / \mathrm{I}$ than $[\mathrm{F} / \mathrm{G}]$ NOC/oFQ (1-13) $\mathrm{NH}_{2}$, these data also suggest that NMDA receptor activation impairs hypotensive dilation by mechanisms independent of NOC/oFQ. No regional vascular or stimulus potency differences in the protective role for MK801 were observed. The concentration of MK801 used for investigation was efficacious for inhibition of NMDA receptor activation in that dilation to this agonist was blocked by MK801.

Glutamate is an important excitatory amino acid transmitter in the brain. It can bind to any of three different inotropic receptor subtypes named after specific synthetic analogs: NMDA, kainate, and $\alpha$-amino-3-hydroxy-5-methylisoxazole4-propionic acid. Activation of NMDA receptors has been observed to elicit cerebrovascular dilation and may represent one of the mechanisms for the coupling of local cerebral metabolism to blood flow (14). Several studies have observed that NMDA-induced pial artery dilation was attenuated after hypoxia or global cerebral ischemia-reperfusion $(15,16)$.

The mechanism by which NMDA-induced pial artery dilation is altered after global cerebral $\mathrm{I} / \mathrm{R}$ or $\mathrm{H} / \mathrm{I} / \mathrm{R}$ is unclear at this time. Recent work by others suggests a role for oxygen free radicals and protein synthesis $(16,17)$. In that proposed scenario, increased cyclooxygenase synthesis might account for the previously observed role for oxygen free radicals in I/R-associated cerebrovascular derangement (17). Alternatively, the observed beneficial action of protein synthase inhibitors might relate to the block of the production of an unidentified regulatory protein that is rapidly overexpressed after ischemia (17). Interestingly, adenosine, which is released during hypoxia, has been observed to inhibit NMDA-induced pial artery dilation when coadministered with this excitatory amino acid (6), very similarly to the observations with $\mathrm{NOC} /$ oFQ. In those studies it was suggested that adenosine might reduce calcium entry into nerve cells and activation of nitric oxide synthase by promoting hyperpolarization or by blocking $\mathrm{N}$ - and Q-type channels (16). It was further suggested that adenosine might reduce presynaptic glutamate release and thus suppress autoamplification of glutamate effects (16). Equally interesting, then, is the observation that $\mathrm{NOC/oFQ}$ can inhibit the release of glutamate from rat cerebrocortical slices and inhibit glutamatergic transmission in the rat spinal cord (18, 19). NOC/oFQ signaling can also be modulated by NMDA (20). More distal mechanisms by which NOC/oFQ-induced $\mathrm{O}^{-}{ }_{2}$ generation might alter NMDA-induced pial artery dilation (13) are currently uncertain.

The experimental design of the present study did not allow for the identification of the cellular site of origin for NOC/oFQ detected in cortical periarachnoid CSF. Potential cellular sites of origin include neurons, glia, vascular smooth muscle, and endothelial cells.

Results of the present study extend those that previously observed an impairment of hypotensive pial artery dilation after global cerebral ischemia (8). Such results indicate that the NOC/oFQ and glutamate released after H/I $(5,21)$ contribute to cerebrovascular dysregulation after insult. Conversely, however, it has also been observed that both $\mathrm{NOC} / \mathrm{oFQ}$ and $[\mathrm{F} / \mathrm{G}]$ NOC/oFQ (1-13) $\mathrm{NH}_{2}$ can inhibit ischemia-induced efflux of glutamate from rat cerebrocortical slices (22), resulting in uncertainty as to whether NOC/oFQ is neuroprotective or a contributor to neuropathology.

\section{CONCLUSION}

In conclusion, results of the present study show that $\mathrm{NOC} /$ oFQ and NMDA contribute to H/I hypotensive cerebrovasodilation impairment. These data suggests that NOC/oFQ modulation of NMDA vascular activity also contributes to such hypotensive vascular impairment.

Acknowledgment. I thank John Ross for excellent technical assistance in the performance of the experiments.

\section{REFERENCES}

1. Volpe JJ 1998 Brain injury in the premature infant: overview of clinical aspects, neuropathology, and pathogenesis. Semin Pediatr Neural 5:135-151

2. Meunier JC 1997 Nociceptin/orphanin FQ and the opioid receptor-like ORL1 receptor. Eur J Pharmacol 340:1-15

3. Reinscheid RK, Nothacker HP, Bourson A, Ardati A, Henninsen RA, Bunzow JR, Grandy DK, Langen H, Monsma Jr FJ, Civelli O 1995 Orphanin FQ: a neuropeptide that activates an opioidlike G protein-coupled receptor. Science 270:792-794

4. Meunier JC, Mollereau L, Toll C, Suaudeau C, Moisdan P, Alvinerie JL, Butour JC, Guillemot P, Ferrara P, Monsarrat B, Mazarguil H, Vassart G, Parmentier M, Costenin J 1995 Isolation and structure of the endogenous agonist of opioid receptorlike OR1 receptor. Nature 377:532-535

5. Armstead WM 2000 Relationship between nociceptin/orphanin FQ and cerebral hemodynamics after hypoxia/ischemia in piglets. Am J Physiol 278:H477-H483

6. Armstead WM 2000 NOC/oFQ contributes to hypoxic/ischemic impairment of $N$-methyl-D-aspartate-induced vasodilation. Brain Res 868:48-55 
7. Laudenbach V, Calo G, Guerrini R, Lamboley G, Benoist JF, Evard P, Gressens P 2001 Nociceptin/orphanin FQ exacerbates excitotoxic white matter lesions in the murine neonatal brain. J Clin Invest 107:457-466

8. Leffler CW, Busija DW, Beasley DG, Armstead WM, Mirro R 1989 Postischemic microvascular cerebral responses to norepinephrine and hypotension in newborn pigs. Stroke 20:541-546

9. Leffler CW, Busija DW, Mirro R, Armstead WM, Beasley DG 1989 Effects of ischemia on brain blood flow and oxygen consumption of newborn pigs. Am J Physiol 257:H1917-H1926

10. Guerrini R, Calo G, Rizzi A, Bigoni R, Bianchi C, Salvadori S, Regoli D 1998 A new selective antagonist for the nociceptin receptor. Br J Pharmacol 123:163175

11. Kapusta DR, Chang JK, Kenigs VA 1999 Central administration of $\mathrm{Phe}^{1} \Psi\left(\mathrm{CH}_{2}\right.$ $\mathrm{NH}) \mathrm{Gly}_{2}$ )y nociceptin (1-13) $\mathrm{NH}_{2}$ and orphanin $\mathrm{FQ} /$ nociceptin $\mathrm{OFQ} / \mathrm{N}$ produce similar cardiovascular and renal responses in conscious rats. J Pharmacol Exp Ther 289:173-180

12. Armstead WM 1999 Nociceptin/orphanin FQ dilates pial arteries by $K_{\mathrm{ATP}}$ and $\mathrm{K}_{\mathrm{c}}$ channel activation. Brain Res 835:315-323

13. Armstead WM $2000 \mathrm{NOC} / \mathrm{oFQ}$ dependent superoxide generation contributes to hypoxic/ischemic impairment of NMDA cerebrovasodilation. Am J Physiol 279:H2678-H2684

14. Faraci FM, Breese KR 1993 Nitric-oxide mediates vasodilation in response to activation to $N$-methyl-D-aspartate receptors in the brain. Circ Res 72:476-480
15. Busija DW, Meng W, Bran F, McGough S, Errico RA, Tobin JR, Louis TM 1996 Effects of ischemia on cerebrovascular responses to $N$-methyl-D-aspartate in piglets. Am J Physiol 270:H1225-H1230

16. Bari F, Thore CL, Louis TM, Busija DW 1998 Inhibitory effects of hypoxia and adenosine on $N$-methyl-D-aspartate-induced pial arteriolar dilation in piglets. Brain Res 780:237-244

17. VeltKamp R, Domoki F, Bari F, Louis TM, Busija DW 1999 Inhibitors of protein synthesis preserve the $N$-methyl-D-aspartate-induced cerebral arteriolar dilation after ischemia in piglets. Stroke 30:148-152

18. Faber ESL, Chambers JP, Evans RH, Henderson G 1996 Depression of glutamatergic transmission by nociceptin in the neonatal rat hemisected spinal cord preparation in vitro. Br J Pharmacol 189:189-190

19. Nicol B, Lambert DG, Rowbothan DJ, Smart D, McKnight AT 1996 Nociceptin induced inhibition of $\mathrm{K}^{+}$evoked glutamate release from rat cerebrocortical slices. Br J Pharmacol 119:1081-1083

20. Zhao J, Zhany Y, Xin S-M, Pei G 1998 Attenuation of nociceptin/orphanin FQinduced signaling by $N$-methyl-D-aspartate in neuronal cells. Neuroreport 9:631-636

21. Inder TE, Volpe JJ 2000 Mechanisms of perinatal brain injury. Semin Neonatal 5:3-16

22. Nelson RM, Calo G, Guerrini R, Hains AH, Green AR, Lambert DG 2000 Nociceptin/orphanin FQ inhibits ischemia induced glutamate efflux from rat cerebrocortical slices. Neuroreport 11:3689-3692 